KuLTura - meDia - TeoLogia ISSN 2081-8971

$2017 \mathrm{nr} 29$, s. 127-143.

\title{
Hejting i trolling w kontekście kanonów 1364 i 1369 Kodeksu Prawa Kanonicznego
}

Hejting and trolling in the context of canons 1364 and 1369 of the Code of Canon Law.

\begin{abstract}
STRESZCZENIE:
Zestawianie Prawa Kanonicznego z hejtingiem I TROLINGIEM MOŻE POCZĄTKOWO WYWOŁYWAĆ WRAŻENIE ZDERZENIA ZE SOBĄ DWÓCH ODDZIELNYCH ŚWIATÓW. JEDNAKŻE WPISY W MEDIACH SPOŁECZNOŚCIOWYCH MOGĄ NOSIĆ ZNAMIONA HEREZJI, APOSTAZJI LUB SCHIZMY. KANON 1364 PRZEWIDUJE ZA NIE EKSKOMUNIKE LATAE SENTENTIAE. ARTYKUŁ MA NA CELU UKAZANIE MOŻLIWOŚCI TEORETYCZNYCH ZACIĄGNIĘCIA TEJ KARY ZA KOMENTARZE INTERNETOWE. Twórcy Kodeksu Prawa Kanonicznego wskazują NA JEGO EWANGELICZNĄ GENEZE. W ZWIĄZKU Z TYM EKSKOMUNIKA JEST KARĄ UŻYWANĄ W OSTATECZNOŚCI. ANALIZA UKAZUJE, ŻE PRZEEOŻENI KOŚCIELNI CHĘTNIEJ SIĘGAJĄ PO KARĘ ZAKAZU WYPOWIEDZI MEDIALNYCH, KTÓRA MOŻE BYĆ SKUTKIEM KANONU 1369. NIEDOSTOSOWANIE SIĘ DO NIEJ SKUTKUJE KARĄ SUSPENSY, KTÓRA WYNIKA NIE TYLKO Z BRAKU POSŁUSZEÉSTTWA, ALE I Z WYPOWIEDZI MEDIALNYCH GODZĄCYCH W DOBRE IMIĘ KOŚCIOŁA.
\end{abstract}

\section{SŁOWA KLUCZOWE:}

HEJTING, TROLLING, PRAWO KANONICZNE, SUSPENSA, EKSKOMUNIKA

\begin{abstract}
:
COMPARING CANON LAW WITH HEATING AND TROLLING MAY CAUSE THE IMPRESSION OF TWO DIFFERENT WORLDS. HOWEVER SOCIAL MEDIA POSTS MAY BE MARKED WITH THE STIGMA OF HERESY, APOSTASY OR SCHISM. THE PENALTY FOR THESE CRIMES PREDICT BY THE CANON 1364 IS THE LATAE SENTENTIAE EXCOMMUNICATION. THIS ARTICLE IS INTENDED, TO SHOW THEORETICAL POSSIBILITIES OF ENFORCING THIS PUNISHMENT FOR INTERNET COMMENTS. AUTHORS OF THE CODE OF CANON LAW INDICATE ITS EVANGELICAL GENESIS. THEREFORE, EXCOMMUNICATION IS A PUNISHMENT USED ONLY AS A LAST RESORT. THE ANALYSIS DEPICTS THAT, CHURCH SUPERIORS PREFER REACH FOR RETRIBUTION OF MEDIA STATEMENTS BAN, WITCH MAY BE THE EFFECT OF THE CANON 1369. NO ADAPTING TO IT RESULTS IN SUSPENSE PENALTY WITCH STEMS FROM THE LACK OF OBEDIENCE AND THE MEDIA STATEMENTS THAT DISCREDIT THE Church'S GOOd NAmE.

Teum. Sonia StefańsKa.
\end{abstract}

\section{KEYWORDS:}

HEJTING, TROLLING, CANON LAW, SUSPENSA, EXCOMMUNICATION 
$\mathrm{Z}$ estawianie Prawa Kanonicznego $\mathrm{z}$ hejtingiem i trolingiem może początkowo wywoływać wrażenie zderzenia ze sobą dwóch oddzielnych światów. Ten swego rodzaju dysonans poznawczy łączy w logiczną całość podmiot obu działań. Należy zatem na początku określić podmiot prawa kanonicznego, aby w kolejnym kroku wskazać, jaki zakres działań podlega przestępstwom zawartym w tytularnych kanonach. Kolejny krok to określenie zjawiska hejtingu i trolingu. Na przykładzie religijnego wymiaru wypowiedzi tego typu, zostanie ukazana możliwość zaciągnięcia winy i kary, a następnie przedstawiona zostanie praktyka Kościoła dotycząca zagadnienia.

\section{Podmiot i specyfika Prawa Kanonicznego}

Kodeks Prawa Kanonicznego w kanonie 11 określa warunki, których spełnienie czyni osobę podmiotem względem prawa Kościoła. Pierwszy z nich to chrzest w Kościele katolickim lub wstąpienie ochrzczonego z innego obrządku. Oznacza to, że wyznawcy innych religii nie są związani przepisami, które stanowią treść niniejszego opracowania. Drugi warunek wypływa bezpośrednio z prawa naturalnego i stanowi, że osoba musi posiadać wystarczające używanie rozumu. Zgodnie z kanonem 1321 kodeksu § 3, gdy nastąpił czyn zabroniony, domniemywa się, że sprawca był poczytalny. Stwierdzenie to obowiązuje, aż do czasu, gdy udowodni się stan przeciwny. Bardziej szczegółowo rozważania dotyczące poczytalności podmiotu względem prawa kanonicznego przedstawia ks. Grzegorz Leszczyński ${ }^{1}$. Ostatnim warunkiem powodującym podleganie jurysdykcji kościelnej jest ukończenie 7 . roku życia. Wiek ten jest granicą pomiędzy brakiem zdolności używania rozumu, a możliwością korzystania z niego w sposób ograniczony².

Prawo kanoniczne oparte jest na fundamencie Ewangelii ${ }^{3}$. Posiada ono zatem swoje specyficzne cechy, które sprawiają, że jest ono całkowicie odmienne od prawa cywilnego ${ }^{4}$. Podstawową różnicę stanowi podejście do zagadnienia priorytetowego w logice prawa cywilnego, jakim jest relacja winy i kary. Pierwszym celem prawa kanonicznego nie jest analiza wyłącznie faktu popełnienia wykroczenia czy przestępstwa, ale przede wszystkim wymiar duszpasterski ${ }^{5}$. Oznacza to, że ponad sprawiedliwością związaną z wymierzeniem kary, znajduje się chęć pomocy zagubionym w wierze braciom, w naśladowaniu Boga i przeżywaniu wspólnoty Mistycznego Ciała Chrystusa. Perspektywa soteriologiczna powoduje, że człowiek zawsze stoi w pierwszeństwie nad kazusami. Kary w Kościele dzielą się na cenzury, czyli te, które mają wymiar popraw-

\footnotetext{
1 G. Leszczyński, Pojęcie poczytalności w prawie karnym kościoła, „Łódzkie Studia Teologiczne” 2002$2003 \mathrm{nr} 11-12$, s. 103 - 117.

2 Kanon 11, KPK.

3 H. M. Jagodziński, Człowiek wobec Ewangelii i prawa kanonicznego, „Kieleckie Studia Teologiczne” $2014 \mathrm{nr} 13$, s. 41 , s. 39-48

4 K. Nykiel, Wyłączenie wiernych ze wspólnoty z kościołem. Aspekty prawne i teologiczne, „Roczniki Nauk Prawnych” 2014 t. 24, s. 137-157.

$5 \quad$ Tamże, s. 137.
} 
czy i służą powstrzymaniu zachowania oraz rozpoczęciu pokuty, oraz ekspiacyjne, czyli skutkujące nakazem lub zakazem przebywania w określonym miejscu, pozbawieniem władzy, urzędu, tytułu czy odznaczenia, aż do wydalenia ze stanu duchownego włącznie. Najpoważniejszą karą w Kościele jest ekskomunika, która może mieć charakter kary działającej na mocy samego prawa (tzw. latae sententiae) tzn. obowiązuje za samo popełnienie jakiegoś czynu lub kary wymierzanej lub deklarowanej przez kompetentną władzę Kościelną. Przedmiotem naszych rozważań jest kanon 1364, który należy do kar latae sententiae.

\title{
Przedmiot kanonu 1364
}

Zastanawiając się nad możliwością zaciągnięcia winy i kary na podstawie kanonu 1364 przez działanie związane z komentarzami internetowymi, niezbędna jest szczegółowa analiza przepisu. W pełnym brzmieniu stanowi on:

\begin{abstract}
„Kan. 1364 - § 1. Odstępca od wiary, heretyk lub schizmatyk podlega ekskomunice wiążącej mocą samego prawa, przy zachowaniu przepisu kan. $194^{6}$, $\S 1$, n. 2; duchowny może być ponadto ukarany karami, o których w kan. $1336^{7}$, § 1, n. 1,2 i 3.§ 2. Jeśli tego domaga się długotrwały upór lub wielkość zgorszenia, można dołączyć także inne kary, nie wyłączając wydalenia ze stanu duchownego".
\end{abstract}

Pojęcia apostazji, herezji i schizmy wyjaśnia w literalny sposób kanon 751. Odstępstwo od wiary definiuje on jako całkowite porzucenie wiary chrześcijańskiej. Określenie całkowite powoduje to, że musi być ono zarówno na płaszczyźnie wewnętrznej, jak i zewnętrznej. W związku z tym, zaprzestanie praktyk religijnych nie stanowi apostazji. Zgodnie z procedurą zatwierdzoną przez Episkopat, akt apostazji musi zostać złożony osobiście w formie pisemnej przed proboszczem swojego miejsca zamieszkania. Nie wywołuje zatem skutków prawnych oświadczenie przesłane pocztą, tak zwykłą jak i elektroniczną, lub złożone przed urzędnikiem cywilnym ${ }^{8}$.

Kanon 751, herezją nazywa uporczywe, po przyjęciu chrztu, zaprzeczanie jakiejś prawdzie, w którą należy wierzyć wiarą boską i katolicką, albo uporczywe powąt-

$6 \quad$ Kan. 194 - § 1. Mocą samego prawa zostaje usunięty z urzędu kościelnego: 1 kto utracił stan duchowny; 2 kto publicznie odstąpił od wiary katolickiej lub wspólnoty z Kościołem; 3 duchowny, który usiłował zawrzeć małżeństwo, choćby tylko cywilne. § 2. Usunięcie, o którym w nn. 2 i 3, tylko wtedy. może być urgowane, jeżeli wiadomo, że stwierdziła to kompetentna władza.

$7 \quad$ Kan. 1336 - $\$ 1$. Kary ekspiacyjne, które mogą obowiązywać przestępcę albo na stałe, albo na czas określony lub nieokreślony, oprócz innych, ustanowionych ewentualnie ustawą, są następujące: 1 zakaz lub nakaz przebywania na określonym miejscu lub terytorium; 2 pozbawienie władzy, urzędu, zadania, prawa, przywileju, uprawnienia, łaski, tytułu, odznaczenia, nawet czysto honorowego; 3 zakaz korzystania z tego, co wyliczono w n. 2, lub zakaz korzystania z tego w określonym miejscu lub poza określonym miejscem; tego rodzaju zakazy nigdy nie powodują nieważności;

8 Dekret Ogólny Konferencji Episkopatu Polski w sprawie wystąpień z Kościoła oraz powrotu do wspólnoty Kościoła, „Akta Konferencji Episkopatu Polski” 2015 nr 27, s 101-104. 
piewanie o niej. Określenie „uporczywe” wskazuje na działanie w pełni świadome i dobrowolne przeciw wierze i Urzędowi Nauczycielskiemu Kościoła. Szczegółowe wytyczne odnoszące się do prawd wiary, których dotyczy herezja podaje kanon $750^{9}$. Na mocy przepisów dotyczących przestępstwa, aby herezja zaistniała w sposób faktyczny, nie wystarczy, aby była ona ogłoszona, ale musi zostać zrozumiana i zauważona przez odbiorców. Dodatkowo, istotnym elementem zaciągnięcia winy, jest kontekst wyrażania myśli. Przedstawianie nawet śmiałych tez na pograniczu wiary, jest dopuszczalne $\mathrm{w}$ debacie teologicznej ${ }^{10}$.

Ostatnim przestępstwem, wymienionym w kanonie 1364, jest schizma. Prawo określa ją jako odmowę uznania zwierzchnictwa Biskupa Rzymskiego lub utrzymywania wspólnoty z członkami Kościoła, uznającymi to zwierzchnictwo. Wspólnota Kościoła jest rozumiana nie tylko względem papieża, ale rozciąga się również na Kolegium Biskupów i poszczególnych biskupów w ich diecezjach. Istotą schizmy jest odłączenie się od wspólnoty, nie natomiast zwykłe nieposłuszeństwo wobec przełożonego ${ }^{11}$.

\section{Hejting i trolling w kontekście relig̈̈nym}

Zjawisko hejtingu bywa definiowane na wiele sposobów. Na potrzeby niniejszego artykułu przyjęta zostanie definicja lingwistyczna autorstwa Aliny Naruszewicz-Duchlińskiej, językoznawcy z Uniwersytetu Warmińsko-Mazurskiego, która hejtingiem nazywa „próbę deprecjacji osoby bądź tematu poprzez bezlitosną, najczęściej nieuzasadnioną merytorycznie, ale maksymalnie emocjonalną krytykę" ${ }^{12}$. Analiza komentarzy internetowych w dyskusjach dotyczących religii wskazała, że zjawisko hejtingu w odniesieniu do treści religijnych nie jest jednorodne. Można przyjąć różne kryteria odróżniające poszczególne formy. Klasyfikacja przeprowadzona na potrzeby odniesienia ich do kanonu 1364 KPK, uwypukliła trzy jego rodzaje, które wiążą się bezpośrednio z badanym zagadnieniem. Są to hejting dogmatyczny, liturgiczny i schizmatyczny ${ }^{13}$.

$9 \quad$ Kan. 750 - Wiarą boską i katolicką należy wierzyć w to wszystko, co jest zawarte w słowie Bożym, pisanym lub przekazanym, a więc w jednym depozycie wiary powierzonym Kościołowi i co równocześnie jako przez Boga objawione podaje do wierzenia Nauczycielski Urząd Kościoła, czy to w uroczystym orzeczeniu, czy też w zwyczajnym i powszechnym nauczaniu; co mianowicie ujawnia się we wspólnym uznaniu wiernych pod kierownictwem świętego Urzędu Nauczycielskiego. Wszyscy więc obowiązani są unikać doktryn temu przeciwnych.

Tamże, s.145.

A. Naruszewicz-Duchlińska, Intencjonalne językowe zakłócenia komunikacji internetowej (troling, flaming; hejting) „Prace językoznawcze” 2014 z. 4, s. 90.

13 Zagadnienie hejtingu w odniesieniu do herezji, schizmy i apostazji nie było jeszcze analizowane. W związku z tym proponują nową klasyfikację wpisów internetowych dostosowaną do odniesienia ich do kanonu 1364 KPK. Części tego podziału proponuję nazwać hejtingiem dogmatycznym, liturgicznym i schizmatycznym. Do kategorii dogmatycznej zostały zaliczone wypowiedzi nienawistne i trolujące, które podważają uznane prawdy wiary podane w formie dogmatów. Wpisy podważające obowiązujący w Kościele Katolickim porządek liturgiczny to w hejting lub troling liturgiczny. Do kategorii schizmatycznej zostały zaliczone wszystkie wypowiedzi skierowane przeciw jedności lub strukturze Kościoła. 


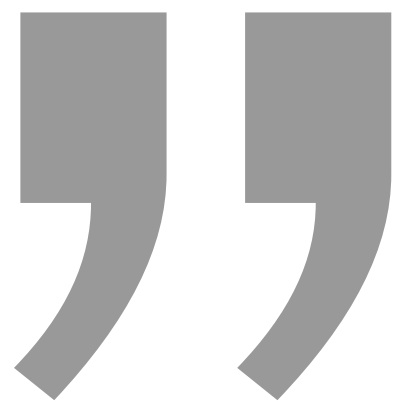

Pierwszym celem prawa kanonicznego nie jest analiza wyłącznie faktu popełnienia wykroczenia czy przestępstwa, ale przede wszystkim wymiar duszpasterski. Oznacza to, że ponad sprawiedliwością związaną z wymierzeniem kary, znajduje się chęć pomocy zagubionym w wierze braciom, w naśladowaniu Boga i przeżywaniu wspólnoty Mistycznego Ciała Chrystusa.

Mocny trend związany z wymienionymi rodzajami hejtingu wynika ze wzrostu popularności nurtu sedewakantyzmu. Nazwa ,,sedewakantyzm” pochodzi od lacińskiego sede vacante. Oznacza okres, kiedy cały Kościół lub pojedyncza diecezja pozostaje bez papieża lub biskupa. Przedstawiciele tego nurtu uważają, że ostatnim prawowicie wybranym papieżem był Pius XII. W związku z powyższym, każdy następny Ojciec Święty jest antypapieżem, a liturgia posoborowa jest wprowadzona w sposób nieprawny ${ }^{14}$. Oficjalnie, grupa osób uważających się za wyznawców tego nurtu w Polsce nie jest liczna, ale ich poglądy dotyczące ważności Soboru Watykańskiego II, w tym liturgii posoborowych, są w mediach społecznościowych chętnie powielane przez część tzw. „środowisk tradycjonalistycznych". Istotnym problemem jest nazewnictwo fanpage'y. Sugerują one, że są jedynymi obrońcami prawdziwej wiary rzymskokatolickiej, specjalistami od nieskażonej liturgii i ostatnią nadzieją Kościoła na powrót do prawowitej nauki. Internauci, zwłaszcza duchowni, dobrze orientujący się w prawowitym nauczaniu Kościoła katolickiego, powinni reagować na błędne informacje w Sieci. Jeśli to możliwe, powinni dodawać swoje komentarze w miejscu, gdzie owa błędna nauka się znajduje. Ponieważ administrator np. sedewakantystów usunie taki tekst, koniecznie powinien się on znaleźć na własnym profilu danego internauty z linkiem do tekstu, którego dotyczy.

Trollingiem nazywamy komentarz służący wywołaniu dezorganizacji dyskusji. Jego istotą jest zaburzenie komunikacji, polegające na uporczywym utrudnianiu funkcjonowania danego gremium, za pomocą prowokacyjnych wpisów, bardzo często nieodnoszących się do komentowanych treści ${ }^{15}$. Analiza komentarzy wskazuje, że troling treści religijnych nie wypełnia czynów przestępstwa określonego kanonem 1364 Kodeksu Prawa Kanonicznego.

14 P. Pawelec, Sedewakantyzm: wybrane zagadnienia, „Resovia Sacra. Studia Teologiczno-Filozoficzne Diecezji Rzeszowskiej” 2009 nr 16, s. 321-335.

15 K. Gajewski, No comment. Z poetyki komentarza elektronicznego, „Zagadnienia Rodzajów Literackich” 2013 z. 2, s. 123. 


\section{Najczęściej hejtowane tematy i miejsca ich występowania}

Wśród wymienionych grup hejtingu, najczęściej poruszane tematy się powtarzają. W przypadku części dogmatycznej dotyczą one asystencji Ducha Świętego podczas Soboru Watykańskiego II ${ }^{16}$, wyboru Ojca Świętego Franciszka, czy uchwalania Konstytucji o Liturgii Świętej. Kolejnym chętnie podejmowanym tematem jest Miłosierdzie Boż $\mathrm{e}^{17}$. Szeroko hejtowany jest też Ekumenizm ${ }^{18}$ jako sprzeczny z nauką Kościoła Katolickiego.

W przypadku hejtingu liturgicznego, zwolennicy rytu tradycyjnego bez zmrużenia okiem określają świętokradcami w pierwszym stopniu szafarzy nadzwyczajnych Komunii Świętej ${ }^{19}$. Z dużą dozą niechęci, okraszonej epitetami, traktowane są również osoby przyjmujące Pokarm Eucharystyczny w postawie stojącej lub w formie na rękę. Sama Liturgia Eucharystyczna nie zostaje oszczędzona w nieprzychylnych komentarzach. Najłagodniejszym określeniem liturgii posoborowej jest nazwanie jej protestancką ${ }^{20}$. Najdosadniejsze natomiast określa ją mianem dzieła szatana ${ }^{21}$.

16 J. Międlar, Kto wybrał Franciszka?, „Nie godzi się obarczać tym wyborem Ducha Świętego”?!, Film na YouTube opublikowany 14.05.2017 r., https://www.youtube.com/watch? v=Tgda8F3vPNY\&feature=youtu.be [dostęp: 18.05.2017].

17 T. Olsz, „Falszywe milosierdzie Bergoglio dla cudzych bogow. Ks. Lukasz Weber FSSPX o antykoscielnej bulli... http://fb.me/6ZMP2pvmy „Wpis na Twitterze na koncie @tereska45 z dnia: 1.01.2016 r. https://twitter.com/tereska45/status/682947355142975489 [dostęp: 21.05.2017].

A. Ostrzenska, „Ekumenizm przyczynia się do utraty wiary wśród katolików, szczególnie w fakt, iż poza Kościołem nie ma zbawienia (tak uczy nasz Pan). Poza tym przyczynia się do utwierdzania innowierców w ich błędach, choć Pan Jezus nakazał „idźcie i nauczajcie wszystkie narody”. Tak więc człowiek, który otrzymał łaskę prawdziwej wiary powinien ją głosić innym" komentarz z dnia 14.05.2017 r. do memu Kto modli się z heretykami sam staje się heretykiem opublikowany na fanpage’u @PortalMysliKonserwatywnej,

https://www.facebook.com/PortalMysliKonserwatywnej/photos/a.273311619486755.1073741828.2732 83746156209/882622078555703/?type=3\&theater [dostęp: 21.05 .2017 ].

W. Kociemba, Skoro mogę dotknąć Ciała Pańskiego przyjmując Go, to dlaczego miałbym nie rozdawać Go innym? Pff! Diabelskie myślenie! I takie odstępstwa są wprowadzane. Dzisiaj mówi się na takich ludzi - szafarze Komunii Świętej, ale gdzie szacunek do Boga?”, komentarz pod memem Komunia Św na rękę na fanpage'u @KatolemJestem z dnia 25.02.2017, https://www.facebook.com/KatolemJestem/photos/a.1410587295821939.1073741830.1410301525850516/1880520665495264/?type=3\&theater [dostęp: 19.05.2017].

Kacper Dobrzyński „Tutaj widać prawdziwe znaczenie Novus Ordo Missae. Przyjęcie myśli od protestantów co do Mszy jako uczy a nie Kalwarii.” Komentarz pod postem Z cyklu aberracje I Komunii Świętej. Oto zgnite owoce herezji modernistycznej! Apostazja! na profilu Marcin Kulpa https://www.facebook.com/marcin.kulpa.507?hc_ref=SEARCH\&fref=nf\# [dostęp: 19.05.2017].

M. Kulpa, ,Jak to możliwe, że Kościół Święty może mieć dwa różne sprzeczne wobec siebie obrzędy Mszy Świętej w jednym rycie rzymskim? Msza Święta (Wszechczasów) która uobecnia Ofiarę Męki i Śmierci Krzyżowej; i nowa msza która wspomina pamiątkę Pana, jest ucztą. Ano nie może mieć podobnie jak wcześniej wykazałem tu w tym przypadku, dwóch sprzecznych wobec siebie Mszy Św. Bo zaprzecza sam Sobie wtedy Kościół Św. Dlatego nowa msza należy do kościoła posoborowego, którym jest antykościół antychrysta.” Komentarz do zdjęcia Ku przestrodze dla każdego z 27.08.2016 na profilu Marcin Kulpa https://www.facebook.com/photo.php? fbid $=528799370645402 \&$ set=a.501932906665382 $1073741840.100005460308416 \&$ type $=3 \&$ theater $[$ do- 
Hejting schizmatyczny jest skoncentrowany na atakach dotyczących papieża Franciszka $^{22}$, episkopatu i poszczególnych biskupów diecezjalnych. W polskojęzycznym internecie często zestawiane są ze sobą osoby papieży Benedykta XVI i Franciszka. Pierwszy z nich jest nazywany ostatnim prawdziwym papieżem, a drugi w tym porównaniu uzurpatorem stolicy apostolskiej ${ }^{23}$. Wzmocnienie poglądu, że obecny Ojciec Święty jest antypapieżem $^{24}$ następuje przez uporczywe pozbawianie go imienia jakie przyją obejmując urząd biskupa Rzymu, na rzecz sformułowań: „Bergoglio ${ }^{25}$ ”, „antypapież Bergoglio ${ }^{26}$ ”i podobne temu. Inną formą hejtingu są sformułowania dotyczące związku Franciszka z „lewackim lobby”. Innym celem hejtingu jest Episkopat Polski, określany mianem loży masońskiej ${ }^{27}$, zbiorem biskupów lewackich ${ }^{28}$.

Wspomniane powyżej zjawiska hejtingu religijnego nie są na szczęście problemem, który występuje bardzo często ${ }^{29}$. Największa liczba tego typu wpisów jest publikowana na fanpage'ach sympatyzujących z sedewakantystami, narodowościowo - nacjonalistycznymi i skrajnie tradycjonalistycznymi ${ }^{30}$. Kolejnym miejscem występowania takich

stęp: 19.05.2017].

22

A. Dobosz, „Pierwsza Bestia, mały róg i fałszywy prorok-wszystkie jego określenia z Biblii. Zwodzi on świat swoją herezją razem z antychrystem, który niedługo zostanie nam przedstawiony jako człowiek pokoju... zobaczycie...”, komentarz do filmu Historia porażki Boga wg. Jorge Bergoglio zamieszczony na fanpage'u @Znaki Czasów Ostatecznych 25.04.2017,

https://www.facebook.com/znakiczasow/videos/1389743627783211/?fref=mentions [dostęp: 18.05.2017].

23 G. Ciosmak, „Myslalem,ze Papiez jest następcą Św. Piotra, opoką,obrońcą Kosciola jako zgromadzenia. Ma jednoczyc, gromadzic i budowac. A ten caly Franciszek nie nadaje sie nawet na pastucha...” (pisownia oryginalna), komentarz do postu z dnia 24.02.2017 na fanpage’u @KatolemJestem https://www.facebook.com/KatolemJestem/?fref=ts\# [dostęp: 19.05.2017].

24 J. M. Sosnowska, „scierwo papieskie,jak kazdy z nich, satanista,z pogietym krzyzem satanistycznym, ktöry poniza Jezusa !”, Tamże. [dostęp: 19.05.2017].

25 Nautulicus, „Swięta prawda : Bergoglio byl protegowanym kard Martiniego slynnego masona! Kim zatem jest Bergoglio? Papieżem na pewno nie! Jest nim BXVI.”, Tweet z dnia 18.05.2017 na profilu @eb77fba16e834da, https://twitter.com/eb77fba16e834da/status/865222401466007552 , [dostęp: 21.05.2017].

26 Młot na posoborowe, Antypapież znowu nadaje !!, Post na profilu @przedsoborowy z 22.03.2017, https://www.facebook.com/przedsoborowy/posts/1246141055441139 [dostęp: 18.05.2017]. J. Międlar, Kto wybrał Franciszka?... [dostęp: 19.05.2017].

28 B. Czekaski, „Lewacki papież, a teraz nasi biskupi...” wpis z dnia 6.05.2017 r. https://www.facebook.com/profile.php?id=100009917862428\&fref=ts [dostęp: 19.05.2017].

Badania własne z dnia 29.04.2017 roku. Przebadano reakcje na 10 ostatnich wpisów na Fanpage’u @CzytamSłowoBoże. Suma wszystkich aktywności wyniosła 2363 z czego: 412 komentarzy werbalnych, 1762 komentarze piktograficzne i 289 podań dalej. Komentarzy hejtujących 2 . Stanowi to $0,49 \%$ komentarzy werbalnych i 0,085\% wszystkich aktywności. Oba wpisy dotyczyły hejtingu schizmatycznego określającego Kościół katolicki jako sektę.

30 Badania własne z dnia 20.05.2017 roku. Przebadano reakcje na ostatnie 10 wpisów na fanpage’u @przedsoborowy. Suma wszystkich aktywności 354 z czego 257 komentarzy werbalnych, 86 komentarzy piktograficznych i 21 podań dalej. Komentarzy hejtujących 37 co stanowi $14 \%$ aktywności werbalnych i $11 \%$ wszystkich aktywności. Według klasyfikacji było 20 komentarzy hejtingu liturgicznego 9 schizmatycz- 
wpisów, są mocno emocjonalne dyskusje związane z komentowaniem wydarzeń religijnych i wypowiedzi księży. W ostatnim czasie media obiegła informacja, że również jeden z polskich eurodeputowanych dokonał wpisu mającego charakter hejtingu schizmatycznego, nazywając papieża Franciszka wcieleniem Lucyfera ${ }^{31}$.

Zjawiskiem pozytywnym jest fakt, że wpisy dokonywane na oficjalnym koncie papieskim na Twitterze @pontifex_pl, nie są celem hejtu dogmatycznego, liturgicznego czy schizmatycznego ${ }^{32}$.

\section{Grzech, a przestępstwo komentarzach internetowych}

Powyższe przykłady hejtingu religijnego bez wątpliwości są działaniami dobrowolnymi. Nikt nie zmusza innej osoby do publikowania treści w portalach społecznościowych. Trudniejszy osąd stanowi kwestia świadomości popełnianego wykroczenia. W przypadku kar kościelnych, kwestia poczytalności odgrywa zasadniczą rolę. Aktywność internetowa może więc być rozważana na dwóch płaszczyznach. Pierwsza z nich - grzech, łączy się z życiem teologalnym. Hejting niewątpliwie podlega wykroczeniom moralnym związanym z szacunkiem godności drugiego człowieka. Pomimo tego, nie każdy grzech schizmy, apostazji czy herezji jest równoznaczny z przestępstwem ${ }^{33}$. Kodeks Prawa Kanoniczego uwzględnił sytuację związaną ze stanem poczytalności podmiotu podejmującego działanie. Część okoliczności ma tak wielki wpływ na ocenę prawną czynu, że ustawodawca uwolnił działających pod wpływem tychże okoliczności, od każdego rodzaju kary. Są one przedstawione w kanonie $1323^{34}$. Natomiast kanon $1324^{35}$ wymienia takie okolicz-

nego i 6 dogmatycznego.

Prawo do dobrego imienia, „Gość Niedzielny” 07.01.2017 r., http://gosc.pl/doc/3641070.Prawo-do-dobrego-imienia [dostęp: 30.12.2016].

P. Wajs, Zjawisko hejtingu i trolingu na@ponfitex_pl., Analiza tweetów na przykładzie profilu papieża Franciszka, „Kultura - Media - Teologia” 2016 nr 25, s. 59-70.

G. Leszczyński, art. cyt., s.109.

Kan. 1323 - Nie podlega żadnej karze, kto w chwili przekraczania ustawy lub nakazu: 1 nie ukończył jeszcze szesnastego roku życia; 2 naruszył ustawę lub nakaz z ignorancji niezawinionej; na równi zaś z ignorancją stoi nieuwaga i błąd; 3 działał pod wpływem przymusu fizycznego lub na skutek przypadku, którego nie mógł przewidzieć lub przewidzianemu zapobiec; 4 działał pod wpływem chociażby względnie tylko ciężkiej bojaźni albo z konieczności lub wskutek wielkiej niedogodności, jeśli czynność nie jest wewnętrznie zła ani nie powoduje szkody dusz; 5 działał w zgodnej z prawem obronie własnej lub kogoś innego przeciwko niesprawiedliwemu napastnikowi, zachowując należny umiar; 6 nie posiadał używania rozumu, z zachowaniem przepisów kan. 1324, § 1, n. 2 i 1325; 7 sądził bez winy, że zachodzi jedna z okoliczności, o jakich w n.4 lub 5.

Kan. 1324 - $§ 1$. Sprawca przekroczenia nie jest wolny od kary, lecz kara przewidziana ustawą lub nakazem powinna być złagodzona lub zastąpiona pokutą, jeśli przestępstwo zostało popełnione: 1 przez tego, kto posiadał tylko niezupełne używanie rozumu; 2 przez tego, kto nie posiadał używania rozumu wskutek zawinionego nadużycia alkoholu lub podobnego zaburzenia umysłowego; 3 na skutek poważnego wzburzenia uczuciowego, które jednak nie wyprzedziło i nie przekreśliło całkowicie świadomości i zgody woli, jeśli samo wzburzenie nie zostało dobrowolnie wywołane lub nie było podtrzymywane; 4 przez małoletniego, który ukończył szesnasty rok życia; 5 przez tego, kto działał przymuszony ciężką bojaźnią, chociażby tylko względnie, albo z konieczności lub wielkiej niedogodności, jeśli przestępstwo jest we- 
ności działania, które nie powodują odstąpienia od wymierzenia kar, a jedynie zmniejszają ich wymiar. Najmocniejszą formą złagodzenia kary jest zastąpienie jej pokutą. Paragraf 2 tego kanonu jest jednak bardzo istotny w odniesieniu do rozpatrywanego kanonu 1364. Mówi on, że wszystkie wymienione okoliczności uwalniają od kar obowiązujących na mocy samego prawa. Badając wpisy w portalach społecznościowych i mając na uwadze szereg okoliczności, które można wyczytać z analizy lingwistycznej i emocjonalnej dyskusji, można z dużą dozą pewności stwierdzić, że na podstawie kanonów 1323 i 1324, niemożliwe jest zaciągnięcie za sprawą komentarza internetowego kary latae sententiae. Pomimo uwolnienia od przestępstwa i odpowiedzialności za nie, istotna pozostaje kwestia grzechu. Komentarz internetowy jest zawsze działaniem świadomym i dobrowolnym. Hejting i troling w kwestiach wiary może spowodować zgorszenie lub zachwianie wiary u osoby czytającej wpis. Ponadto, jest on raną zadaną Mistycznemu Ciału Chrystusa. Należy zatem mieć świadomość popełniania grzechu, który należy wyznać w sakramencie pokuty, a wyrządzoną szkodę zadośćuczynić względem Kościoła. Pomimo tego, wspólnota Kościoła ma możliwość obrony przed hejtingiem za pomocą kanonu 1369 prawa kościelnego.

\section{Przedmiot kanonu 1369}

Aktualnie obowiązujący Kodeks Prawa Kanonicznego powstawał, gdy o hejtingu i trolingu nikt jeszcze nie słyszał. Pracujący nad nim uwzględnili jednak doświadczenia związane z innymi mediami. Skutkiem tego znalazł się w nim zapis kanonu 1369, który brzmi:

„Kto w publicznym widowisku, w kazaniu, w rozpowszechnionym piśmie albo w inny sposób przy pomocy środków społecznego przekazu, wypowiada bluźnierstwo, poważnie narusza dobre obyczaje albo znieważa religię lub Kościół bądź wywołuje nienawiść lub pogardę, powinien być ukarany sprawiedliwą karą".

Zakres przedmiotowy kanonu 1369 jest bardzo szeroki, a uwzględnienie w nim wypowiedzi związanych z nienawiścią i pogardą wpisuje się doskonale wdefinicje mowy nienawiści, które powstały dwie dekady później. Sformułowanie „przy pomocy środków społecznego przekazu” obejmuje swoim desygnatem Internet, w tym zwłaszcza strony WWW, social media (Facebook, Twitter itp.) i aplikacje społecznościowe

Największym zagrożeniem dla katolików korzystających z mediów społecznościowych, jest niska świadomość tego, czym one faktycznie są. Konta na nich, najczęściej są traktowane, jako miejsce spotkania znajomych, dyskusji z nimi, wymiany informacji,

wnętrznie złe lub powoduje szkodę dusz; 6 przez tego, kto działał w zgodnej z prawem obronie własnej lub kogoś innego przeciwko niesprawiedliwemu napastnikowi, ale nie zachował koniecznego umiaru; 7 przeciwko poważnie i niesłusznie prowokującemu; 8 przez tego, kto z własnej winy był błędnie przekonany, że zachodzi jedna z okoliczności, o których w kan. 1323, n. 4 lub 5; 9 przez tego, kto bez winy nie wiedział, że do ustawy lub nakazu została dołączona kara; 10 przez tego, kto działał bez pełnej poczytalności, o ile ta pozostała wielka. 
grup dyskusyjnych, uzewnętrzniania swoich sympatii lub antypatii i wielu innych funkcji, ale brak w nich świadomości publikowania w pełnoprawnym medium. Dopiero zestawienie ze sobą liczby użytkowników mających dostęp do telewizji naziemnej i tych korzystających z mediów społecznościowych, rozwiewa wszelkie wątpliwości odnośnie do zrównania ze sobą skutków działania tych dwóch mediów. Według raportu Krajowej Rady Telewizji i Radiofonii, w IV kwartale 2016 r. dostęp do telewizji posiadało $15 \mathrm{mln}$ 800 tys. osób ${ }^{36}$. Natomiast według raportu „Digital in 2017 Eastern Europe” z mediów społecznościowych korzysta w Polsce około 15 milionów osób. Gdyby jednak porównywać możliwości dostępu do mediów społecznościowych i telewizji, to liczba użytkowników internetu wynosi ponad 27,92 milionów ${ }^{37}$.

Wobec powyższego, niepokojącym zjawiskiem jest brak świadomości tego, iż wypowiedzi na portalach społecznościowych są publiczne. Należy zatem pamiętać, że nie istnieje w nich taka kategoria jak wypowiedź prywatna. Szczególnie ważne jest to w przypadku osób duchownych. Papież Benedykt XVI podkreśla, że portale społecznościowe wymagają od chrześcijanina autentyczności, nie może on mieć dwóch twarzy: realnej i wirtualnej ${ }^{38}$. Zamieszczając wpis, komentując, czy podając dalej jakieś treści, wypowiadamy się w sposób publiczny. Należy więc mieć świadomość tego, że komentarz internetowy nie różni się co do istoty od komentarza zamieszczonego w gazecie czy stacji telewizyjnej.

W związku z powyższym należy mieć na uwadze, że komentarze internetowe podlegają przedmiotowi przepisu 1369 Kodeksu Prawa Kanonicznego.

\section{Kary w Kościele w praktyce}

Kościół w rozważaniach na temat kar przypomina o łączności prawa kanonicznego z Ewangelią. Skutkiem tego, prawo kanoniczne stara się unikać wymierzania kary i jest ona ostatecznością w przypadku, gdy nie odniosło skutku ani braterskie upomnienie, ani nagana, ani też jakikolwiek inny środek pasterskiej troski ${ }^{39}$. Najczęściej stosowaną karą w Kościele jest suspensa. Może ona zostać nałożona jedynie na osobę duchowną.

W komunikatach medialnych dotyczących suspensy, według wyszukiwarki Google $^{40}$, cztery najbardziej medialne kary, jakie zostały nałożone i były komentowane

36 J. Reisner, Rynek telewizyjny w IV kwartale 2016 roku, KRRiT, Warszawa 2016, http://www.krrit.gov.pl/Data/Files/_public/Portals/0/Nadawcy/aktualnosci/rynek-telewizyjny-w-iv-kwartale-2016.pdf, [dostęp: 22.05.2017].

S. Kemp, Digital in 2017 Eastern Europe, https://www.slideshare.net/wearesocialsg/digital-in-2017eastern-europe [dostęp: 22.05.2017].

Benedykt XVI, Orędzie na 45. Dzień Środków Społecznego Przekazu, Prawda, przepowiadanie i autentyczność życia w erze cyfrowej, „L'Osservatore Romano” $2011 \mathrm{nr} 3$, s. 8.

Z. GROCHOLEWSKI, Specyfika prawa Kościoła katolickiego Referat wygłoszony z okazji otrzymania tytułu doktora honoris causa Uniwersytetu im. Adama Mickiewicza w Poznaniu, dnia 7 maja 2004, „Poznańskie Studia Teologiczne” 2004 nr 17, s. 20.

40 Liczba artykułów w pierwszych 100 wynikach wskazanych jako odpowiedź na zapytanie „suspensa” w wyszukiwarce Google w dniu 30.12.2016 r.: ks. Wojciech Lemański (28), Krzysztofa Haramsy (21), Pio- 
w Kościele w Polsce dotyczą księży: Wojciecha Lemańskiego, Krzysztofa Haramsy, Piotra Natanka i Jacka Międlara.

Analizując komunikaty Kurii Warszawsko-Praskiej w sprawie ks. Wojciecha Lemańskiego ${ }^{41}$ można dostrzec, że w jednej z kwestii przedmiotu sporu, a mianowicie wystąpień medialnych, można mieć podejrzenia o naruszenie prawa wyczerpujące znamiona popełnienia przestępstwa z kanonu 1369. Kuria Biskupia, upominając ks. Lemańskiego, posługuje się jednak kanonem 831. Ogranicza on publikacje wiernych w dziennikach, czasopismach i periodykach, które wyraźnie atakują wiarę lub dobre obyczaje, jedynie do sytuacji, w której występuje słuszna i uzasadniona przyczyna. Prawa do publikacji zostają jeszcze wyraźniej ograniczone wobec duchownych i członków instytutów zakonnych, którzy mogą tam publikować jedynie za zgodą ordynariusza miejsca. Ostatecznie tekst zakazu wypowiedzi i suspensy nie został upubliczniony, jednak z komunikatu o nałożeniu kary wynika, że miała miejsce publiczna wypowiedź, którą można podporządkować pod zaproponowane wcześniej zjawisko hejtingu schizmatycznego, jak i hejtingu dogmatycznego. Kulminacją tego pierwszego zjawiska było stwierdzenie zacytowane w komunikacie z dnia 3 sierpnia 2014 r. „biskupi muszą wymrzeć” ${ }^{42}$. O przekroczeniu uprawnień teologów do wolności poszukiwań, zagwarantowanych w kanonie 218, świadczy upomnienie związane z kanonem 753.

Drugim przypadkiem medialnym związanym z suspensą jest osoba ks. Krzysztofa Charamsy. Komunikaty Kurii Pelplińskiej ${ }^{43}$ wskazują, że centrum działań biskupa Ryszarda Kasyny są sprawy moralne. Pierwszy komunikat, wzywający do powrotu na drogę Chrystusowego kapłaństwa, wskazuje na istnienie wypowiedzi podważających nauczanie Pisma Świętego i Magisterium Kościoła Katolickiego, jednak to nie one są głównym problemem, na który wskazuje biskup. Doniesienia medialne dotyczące wypowiedzi ks. Charamsy mogących zawierać hejting dogmatyczny, mogą stanowić dalszą część badań, jednak przyjęta $w$ artykule metodologia badania jedynie dokumentów kościelnych wraz z troską o przejrzystość sprawiają, że należy to odłożyć na inną rozprawę.

tra Natanka (18) i Jacka Międlara (10).

41 W sumie opublikowano 25 komunikatów dotyczących działań Księdza Lemańskiego oraz Kurii Warszawsko Praskiej. Najważniejsze z nich to: Oświadczenie Kurii Biskupiej Warszawsko-Praskiej dotyczące wypowiedzi ks. Wojciecha Lemańskiego w radiu TOK FM, 12 lipca 2013 r. http://diecezja.waw.pl/3085; A. Petrowa-Wasilewicz, Ks. Lemański - anatomia rozegrania konfliktu, 19.07.2013r., http://diecezja.waw.pl/3101; Komunikat kurialny dotyczący ks. Wojciecha Lemańskiego, 21 lipca 2013 r., http://diecezja.waw.pl/3102; Komunikat Rzecznika Prasowego Diecezji Warszawsko-Praskiej, 3 sierpnia 2014 r., http://diecezja.waw.pl/3600; Ks. Wojciech Lemański został suspendowany, 22 sierpnia 2014 r., http://diecezja.waw.pl/3628, Komunikat Kurii Biskupiej Warszawsko-Praskiej ws. Ks. Wojciecha Lemańskiego, 20 stycznia 2015 r., http://diecezja.waw.pl/3937 [dostęp: 29.01.2017]. Komunikat Rzecznika Prasowego Diecezji Warszawsko-Praskiej, 3 sierpnia 2014 r., http://diecezja.waw.pl/3600 [dostęp: 29.01.2017]. zja /komunikaty/1267-komunikat-rzecznika-diecezji-pelplinskiej; Komunikat w sprawie ks. Krzysztofa Charamsy, 21.10.2015 r., http://www.diecezja-pelplin.pl/diecezja/komunikaty/1270-komunikat-w-sprawie-ks-krzysztofa-charamsy [dostęp: 29.01.2017]. 
Trzeci, najpopularniejszy medialnie przypadek suspensy, to kara nałożona na ks. Piotra Natanka. Kuria Metropolitalna w Krakowie opublikowała 11 dokumentów dotyczących działalności tego duchownego. Ich analiza wskazuje, że zasadniczą sprawą podnoszoną przeciw jego działalności duszpasterskiej jest niezgodność głoszonych treści z nauczaniem Kościoła ${ }^{44}$. Pierwsze kroki wzywały do zaprzestania własnej interpretacji Pisma Świętego i objawień nieuznanych przez Urząd Nauczycielski Kościoła. Można stwierdzić, że ten pierwszy etap nosił cechy trolingu religijnego. Komentarze ks. Natanka były nadinterpretujące, ozdobione własną retoryką, a stanowiły jedynie wstęp do dalszych aktywności. Kuria Metropolitalna wzywała Natanka nie tylko do zaprzestania działalności, ale również do wycofania zgody na publikacje, w tym internetowe, szkodliwych treści. Pomimo pierwotnych deklaracji posłuszeństwa głoszone treści nie tylko nadal nie mieściły się w granicach poprawnej nauki, ale zostały uzupełnione o wypowiedzi zarzucające władzom Kościoła w Polsce niewiarę i współpracę z wrogami Kościoła. Ten etap, z medialnego punktu widzenia stanowi przejście od trolingu do hejtingu schizmatycznego. Praktyczny wymiar takiego działania Kuria diecezjalna ukazuje jako próby tworzenia własnych struktur wyjętych z jedności Kościoła. Pomimo wyczerpania znamion przestępstwa z kanonu 1364 dotyczących herezji i trwania w nich pomimo upomnień, Kuria Metropolitalna w Krakowie postanowiła zastosować karę mniejszej wagi i ukarać ks. Natanka suspensą. Na powagę zarzutów wskazuje podjęcie tematu błędnego nauczania przez Konferencję Episkopatu Polski ${ }^{45}$. Była to sytuacja wyjątkowa, kiedy to Rada Stała Konferencji Episkopatu Polski wydała oświadczenie ostrzegające przed błędnymi naukami ks. Natanka. Wskazano w nim, że sprawowane przez niego Msze Święte są niegodne i świętokradzkie, a udzielane rozgrzeszenia nieważne. Działalność ks. Natanka i jego współpracowników została określona rozłamem w Kościele. Pomimo nałożonych kar, kapłan nadal prowadzi działalność związaną z publikacjami - tak tradycyjnymi jak i internetowymi - treści niezgodnych z nauczaniem Kościoła. Publikacje rozsyłane przez ks. Natanka zostały negatywnie ocenione przez komisje teologiczne powołane w tym celu ${ }^{46}$.

Ostatnim przykładem, który zostanie omówiony w tym opracowaniu, jest ks. Jacek Międlar. Analiza dokumentów Kościoła, dotycząca tego duchownego, musi ograniczyć się do oświadczeń ks. Kryspina Banko, Wizytatora Polskiej Prowincji Zgromadzenia

44 Najważniejsze dokumenty Komunikat Kurii Metropolitalnej w Krakowie w sprawie działalności ks. Dr. Hab. Piotra Natanka, 02.03.2010 r., http://www.diecezja.pl/duchowni-i-konsekrowani/listy-i-dekrety/ komunikat-kurii-metropolitalnej-w-krakowie-w-sprawie-dzialalnosci-ks-dr-hab-piotra-natanka/; Komunikat Arcybiskupa Metropolity Krakowskiego w sprawie sankcji kanonicznych podjętych wobec ks. Piotra Natanka, 20.07.2011 r., http://www.diecezja.pl/duchowni-i-konsekrowani/listy-i-dekrety/komunikat-arcybiskupa-metropolity-krakowskiego-w-sprawie-sankcji-kanonicznych-podjetych-wobec-ks-piotra-natanka/ [dostęp: 29.01.2017].

Oświadczenie Rady Stałej Konferencji Episkopatu Polski w sprawie ks. Piotra Natanka i jego zwolenników, http://episkopat.pl/oswiadczenie-rady-stalej-konferencji-episkopatu-polski-w-sprawie-ks-piotra-natanka-i-jego-zwolennikow/ [dostęp: 22.05.2017]. 
Księży Misjonarzy, przesłanych do Katolickiej Agencji Informacyjnej ${ }^{47}$. Czytamy w nich, że ojciec Jacek otrzymał całkowity zakaz wystąpień publicznych. Równocześnie ks. Banko podkreśla, że zgromadzenie nie podziela głoszonych przez niego poglądów i w żaden sposób nie popierało i nie popiera skrajnych ruchów nacjonalistycznych. W kolejnym oświadczeniu z dnia 17.08.2016 roku czytamy, że ks. Międlar otrzymał ponowne napomnienie wraz z informacją, że mogą zostać podjęte sankcje kanoniczne ${ }^{48}$. Sankcji tych nie nałożono, ponieważ zakonnik opuścił zgromadzenie w ostatnim tygodniu września 2016 roku. Za wyjątkiem wypowiedzi ks. Międlara nie zostało wydane oświadczenie o nałożeniu na niego suspensy. Jednak opuszczenie domu zakonnego powoduje zakaz sprawowania funkcji zakonnych do czasu powrotu lub znalezienia biskupa, który przyjmie pod swoją jurysdykcję takiego kapłana. Z analizy oświadczeń opublikowanych przez KAI nie można w sposób jednoznaczny określić, których kanonów użyli przełożeni w napominaniu ks. Międlara. Jednak same oświadczenia mówią wyraźnie o mowie nienawiści rozpowszechnianej tak w kazaniach, jak i w środkach społecznego przekazu. Media internetowe zostały bardzo wyraźnie wskazane jako źródło takich wypowiedzi. Należy więc stwierdzić, że przypadek tego zakonnika w sposób pełny wskazuje możliwość popełnienia przestępstwa za pomocą portali społecznościowych.

\section{Wnioski}

Analiza treści wpisów w mediach społecznościowych wskazuje obecność hejtingu i trolingu o charakterze religijnym. Część publikacji w sposób formalny jest związana z przedmiotem kanonu 1364. Cechy takich wpisów pozwalają wyróżnić hejting dogmatyczny, liturgiczny i schizmatyczny. Znaczna część tego typu wypowiedzi jest związana z sympatyzowaniem z poglądami sedewakantystycznymi. Innym powodem jest nadinterpretacja nauczania Kościoła. Pomimo tego, że komentarze często ocierają się o herezję, działania schizmatyczne lub dają pozór apostazji, zaciągnięcie kary w trybie latae sententiae jest w praktyce niemożliwe. Ustawodawca podkreśla ewangeliczny charakter Kodeksu Prawa Kanonicznego i tym samym wskazuje, że kara ekskomuniki, szczególnie na mocy samego prawa, powinna być stosowana w sposób bardzo rozsądny.

Drugi z badanych kanonów, 1369 KPK, jest stosowany. Skutkiem działań są zakazy wypowiedzi wmediach, aw przypadku niedostosowania się do nakazu przełożonego, kolejnym krokiem jest kara suspensy. Kapłani nie są zmuszeni do działania według własnego uznania. Konferencja Episkopatu Polski wskazała jak w przestrzeni medialnej duchowni i osoby zakonne mają się zachowywać. Zostało to opisane w dokumencie Normy Konferencji Episkopatu Polski dotyczące występowania duchownych

\footnotetext{
47 Ks. Jacek Międlar z całkowitym zakazem wystąpień publicznych, 19.04.2016 r., https://ekai.pl/ks-jacekmiedlar-z-calkowitym-zakazem-wystapien-publicznych/; Przełożony zgromadzenia misjonarzy: Nie podzielamy wypowiedzi ks. Jacka Międlara, https://ekai.pl/przelozony-zgromadzenia-misjonarzy-nie-podzielamy-wypowiedzi-ks-miedlara/ [dostęp: 29.01.2017].

48 Przełożony ks. Międlara o dalszym postępowaniu, Denon 17.08.2016 r., http://www.deon.pl/religia/ kosciol-i-swiat/z-zycia-kosciola/art,27108,przelozony-ks-miedlara-o-dalszym-postepowaniu.html, [dostęp: 29.01.2017].
} 
i osób zakonnych oraz przekazywaniu nauki chrześcijańskiej w audycjach radiowych i telewizyjnych ${ }^{49}$. Na szczególną uwagę w kontekście powyższych rozważań zasługuje punkt 8. norm: „Duchowni i członkowie instytutów zakonnych wypowiadający się w mediach winni cechować się wiernością nauce Ewangelii, rzetelną wiedzą, roztropnością i odpowiedzialnością za wypowiedziane słowo, troską o umiłowanie prawdy i owocny przekaz ewangelicznego orędzia”. Dopełnieniem troski o prawidłowy przekaz nauczania w mediach jest punkt 10 norm wskazujący, że zasady te obowiązują również osoby świeckie, szczególnie zaś te, których wypowiedzi w różny sposób mogą być łączone z autorytetem Kościoła. Komentarz wyjaśniający szczegółowo kwestie związane z zasadami obecności duchownych w mediach przedstawia wieloletni Rzecznik Episkopatu Polski ks. Józef Kloch ${ }^{50}$.

Pomimo jasnych norm i wskazania niebezpieczeństw „uwikłania w Sieć” ${ }^{51}$ wciąż zdarzają się duchowni będący bardziej celebrytami i politykami niż duszpasterzami. Należy jednak stwierdzić, że Kościół w Polsce reaguje w sposób właściwy na nadużycia medialne, które zdarzają się w mediach społecznościowych. O sposobie właściwego głoszenia w nich Dobrej Nowiny, przypomina po raz kolejny papież Franciszek w 51. Orędziu na Światowy Dzień Środków Społecznego Przekazu.

\section{BIBLIOGRAFIA:}

Benedykt XVI, Prawda, przepowiadanie i autentyczność życia w erze cyfrowej, Orędzie na 45. Dzień Środków Społecznego Przekazu, „L'Osservatore Romano"2011 nr 3, s. 8.

Biskupi przestrzegają przed ks. Natankiem, 16.01.2012 r., http://www.diecezja.pl/archidiecezja/ aktualnosci/biskupi-przestrzegaja-przed-ks-natankiem/

Dekret Ogólny Konferencji Episkopatu Polski w sprawie wystąpień z Kościoła oraz powrotu do wspólnoty Kościoła, „Akta Konferencji Episkopatu Polski” $2015 \mathrm{nr} 27$, s 101-104.

Fanpage@CzytamSłowoBoże.

https://www.facebook.com/CzytamSlowoBoze/?fref=ts

Fanpage @KatolemJestem https://www.facebook.com/KatolemJestem [dostęp: 18.05.2017].

Fanpage @PortalMysliKonserwatywnej, https://www.facebook.com/PortalMysliKonserwatywnej [dostęp: 21.05.2017].

$49 \quad$ Normy Konferencji Episkopatu Polski dotyczące występowania duchownych i osób zakonnych oraz przekazywaniu nauki chrześcijańskiej w audycjach radiowych i telewizyjnych, „Akta Konferencji Episkopatu Polski” (2005) nr 1, s. 74-76.

J. Kloch, Zasady występowania duchownych w mediach według Konferencji Episkopatu Polski, w: A. Gralczyk, K. Marcyński, M. Przybysz, Media w transformacji, Warszawa 2013, s. 123-131.

51 M. Przybysz, Kapłan w „Sieci” uwikłany. Dylematy obecności księdza w mediach, w: A Gralczyk, K. Marcyński, M. Przybysz, dz. cyt., s. 105-121. 
Fanpage @przedsoborowy, https://www.facebook.com/przedsoborowy [dostęp: 18.05.2017].

Fanpage @Znaki Czasów Ostatecznych,

https://www.facebook.com/znakiczasow [dostęp: 18.05.2017].

Gajewski K., No comment. Z poetyki komentarza elektronicznego, „Zagadnienia Rodzajów Literackich” 2013 z. 2, s. 123.

Grocholewski Z., Specyfika prawa Kościoła katolickiego Referat wygłoszony z okazji otrzymania tytułu doktora honoris causa Uniwersytetu im. Adama Mickiewicza w Poznaniu, dnia 7 maja 2004, „Poznańskie Studia Teologiczne” $2004 \mathrm{nr} 17$, s.20. (20-33).

Jagodziński H. M., Człowiek wobec Ewangelii i prawa kanonicznego, „Kieleckie Studia Teologiczne" 2014 nr 13, s. 41, s. 39-48

Kanał na YouTube Jacek Międlar,

https://www.youtube.com/watch?v=Tgda8F3vPNY\&feature=youtu.b

Kemp S., Digital in 2017 Eastern Europe, https://www.slideshare.net/wearesocialsg/digital-in-2017-eastern-europe [dostęp: 22.05.2017].

Konto na Facebooku, B. Czekaski, https://www.facebook.com/profile.php? id=100009917862428\&fref=ts [dostęp: 19.05.2017].

Konto na Facebooku Marcin Kulpa https://www.facebook.com/marcin.kulpa [dostęp: 19.05.2017].

Konto na Twitterze, Nautulicus, @eb77fba16e834da, https://twitter.com/eb77fba16e834da, [dostęp: 21.05.2017].

Konto na Twitterze, T. Olsz @tereska45 https://twitter.com/tereska45 [dostęp: 21.05.2017].

Kloch J., Zasady występowania duchownych w mediach według Konferencji Episkopatu Polski, w: A. Gralczyk, K. Marcyński, M. Przybysz, Media w transformacji, Warszawa 2013, s. 123-131.

Komunikat Arcybiskupa Metropolity Krakowskiego w sprawie sankcji kanonicznych podjętych wobec ks. Piotra Natanka, 20.07.2011 r., http://www.diecezja.pl/duchowni-i-konsekrowani/listy-i-dekrety/komunikat-arcybiskupa-metropolity-krakowskiego-w-sprawie-sankcji-kanonicznych-podjetych-wobec-ks-piotra-natanka/ (dostęp 29.01.2017 r.).

Komunikat kurialny dotyczący ks. Wojciecha Lemańskiego, 21 lipca 2013 r., http://diecezja.waw.pl/3102; (dostęp 29.01.2017 r.).

Komunikat Kurii Biskupiej Warszawsko-Praskiej ws. Ks. Wojciecha Lemańskiego, 20 stycznia 2015 r., http://diecezja.waw.pl/3937 (dostęp 29.01.2017 r.).

Komunikat Kurii Metropolitalnej w Krakowie w sprawie działalności ks. Dr. Hab. Piotra Natanka, 02.03.2010 r., http://www.diecezja.pl/duchowni-i-konsekrowani/listy-i-dekrety/komunikat-kurii-metropolitalnej-w-krakowie-w-sprawie-dzialalnosci-ks-dr-hab-piotra-natanka/; (dostęp 29.01.2017 r.). 
Komunikat Rzecznika Prasowego Diecezji Warszawsko-Praskiej, 3 sierpnia 2014 r., http://diecezja.waw.pl/3600; (dostęp 29.01.2017 r.).

Komunikat w sprawie ks. Krzysztofa Charamsy, 21.10.2015 r., http://www.diecezja-pelplin.pl/diecezja/komunikaty/1270-komunikat-w-sprawie-ks-krzysztofa-charamsy (dostęp 29.01.2017 r.).

Ks. Jacek Międlar z całkowitym zakazem wystąpień publicznych, 19.04 .2016 r., https://ekai.pl/ks-jacek-miedlar-z-calkowitym-zakazem-wystapien-publicznych/; (dostęp 29.01.2017 r.).

Ks. Wojciech Lemański został suspendowany, 22 sierpnia 2014 r., http://diecezja.waw.pl/3628,

Leszczyński G., Pojęcie poczytalności w prawie karnym kościoła, „Łódzkie Studia Teologiczne” 2002-2003 nr 11-12, s. 103 - 117.

Majchrzak Ł., Mobile i digital w Polsce i na świecie w 2016 r., https://mobirank.pl/2016/01/27/mobile-digital-w-polsce-na-swiecie-2016/ na podstawie http://wearesocial.com/uk/special-reports/digital-in-2016 (dostęp 14.03.2016).

Naruszewicz-Duchlińska A., Intencjonalne językowe zakłócenia komunikacji internetowej (troling, flaming, hejting) „Prace językoznawcze” 2014 z. 4, s. 90 .

Normy Konferencji Episkopatu Polski dotyczące występowania duchownych i osób zakonnych oraz przekazywaniu nauki chrześcijańskiej w audycjach radiowych i telewizyjnych, „Akta Konferencji Episkopatu Polski” (2005) nr 1, s. 74-76

Nykiel K., Wyłączenie wiernych ze wspólnoty z kościołem. Aspekty prawne i teologiczne, „Roczniki Nauk Prawnych” 2014 t. 24, s. 137-157.

Oświadczenie Kurii Biskupiej Warszawsko-Praskiej dotyczące wypowiedzi ks. Wojciecha Lemańskiego w radiu TOK FM, 12 lipca 2013 r. http://diecezja.waw.pl/3085; (dostęp 29.01.2017 r.).

Oświadczenie Rady Stałej Konferencji Episkopatu Polski w sprawie ks. Piotra Natanka i jego zwolenników, http://episkopat.pl/oswiadczenie-rady-stalej-konferencji-episkopatu-polski-w-sprawie-ks-piotra-natanka-i-jego-zwolennikow/ [dostęp: 22.05.2017].

Oświadczenie w sprawie ks. Krzysztofa Charamsy, 03.10.2015 r., http://www.diecezjapelplin.pl/diecezja /komunikaty/1267-komunikatrzecznika-diecezji-pelplinskiej; (dostęp 29.01.2017 r.).

Pawelec P., Sedewakantyzm: wybrane zagadnienia, „, Resovia Sacra. Studia Teologiczno-Filozoficzne Diecezji Rzeszowskiej” $2009 \mathrm{nr}$ 16, 321-335.

Petrowa-Wasilewicz A., Ks. Lemański - anatomia rozegrania konfliktu, 19.07.2013r., http://diecezja.waw.pl/3101; (dostęp 29.01.2017 r.).

Prawo do dobrego imienia, „Gość Niedzielny” 07.01.2017 r., http://gosc.pl/doc/3641070.Prawo-do-dobrego-imienia (dostęp 30.12.2016 r.). 
Przełożony ks. Międlara o dalszym postępowaniu, Deon 17.08.2016 r., http://www.deon.pl/religia/ kosciol-i-swiat/z-zyciakosciola/art,27108,przelozony-ks-miedlara-o-dalszym-postepowaniu.html (dostęp 29.01.2017 r.).

Przełożony zgromadzenia misjonarzy: Nie podzielamy wypowiedzi ks. Jacka Międlara, https://ekai.pl/przelozony-zgromadzenia-misjonarzy-nie-podzielamy-wypowiedzi-ks-miedlara/

Przybysz M., Kapłan w „Sieci” uwikłany. Dylematy obecności księdza w mediach, w: A Gralczyk, K. Marcyński, M. Przybysz, Media w transformacji, Warszawa 2013, s. 105 - 121

Reisner J., Rynek telewizyjny w IV kwartale 2016 roku, KRRiT, Warszawa 2016, http://www.krrit.gov.pl/Data/Files/_public/Portals/0/Nadawcy/aktualnosci/rynek-telewizyjny-w-iv-kwartale-2016.pdf, [dostęp: 22.05.2017].

Uwagi nt. książek rozsyłanych przez ks. Piotra Natanka, http://www.diecezja.pl/archidiecezja /aktualnosci/uwagi-nt-tresci-ksiazek-rozsylanych-przez-ks-piotra-natanka/ (dostęp 29.01.2017 r.).

Wajs P., Zjawisko hejtingu i trolingu na @ponfitex_pl., Analiza tweetów na przykładzie profilu papieża Franciszka, „Kultura - Media - Teologia” $2016 \mathrm{nr} 25$, s. 59-70.

\section{OAUTORZE:}

mgr lic. Piotr Wajs - studia magisterskie na Wydziale Teologicznym U.O. (2000), studia podyplomowe z informatyki (2002), zarządzania oświatą (2005), przedsiębiorczości (2008) na U.O., Licencjat Rzymski (2013), obecnie doktorant na Wydziale Teologicznym U.O. oraz nauczyciel religii i informatyki w Zespole Szkót Ogólnokształcących $\mathrm{nr} 1 \mathrm{w}$ Opolu. Autor publikacji: Audiowizualne przedstawienia objawienia fatimskiego w mediach społecznościowych na przykładzie serwisu YouTube, Święty Jan Paweł II w mediach społecznościowych, „Ćwierkający papieże” - mikroblogi Benedykta XVI i Franciszka, Zjawisko hejtingu i trolingu na @ponfitex_pl., Analiza tweetów na przykładzie profilu papieża Franciszka, Polskojęzyczne publikacje homilii w serwisie YouTube jako XXI-wieczne zbiory homiletyczne.

Kontakt:piotr.wajs@zhr.pl 